\title{
Participation of city residents in the ongoing activities of public transportation providers
}

\begin{abstract}
The organization and management of public transportation is one of the most important responsibilities of local authorities. In view of the dynamically changing conditions of modern cities' transportation policies, actions in this area pose a challenge, involving the standardization of transportation and its adjustment to the transportation needs and expectations of residents not only of individual cities, but of entire metropolitan areas. One of the ways to tailor transportation to the needs of residents is to continuously coordinate on the basis of diagnosis and analysis of residents' demands. Public transportation passenger councils provide a forum for exchanging views on this issue. In Poland, only the authorities of Warsaw have thus far decided to establish such a body.
\end{abstract}

Key words: urban public transportation management, functional areas of large cities, civic participation

S tudies on new methods of managing local government units emphasize the need to expand the involvement of the general public in the shaping of urban policy. Attention should be paid to studies which connect the problem of low turnout in the elections of representatives for auxiliary units, in local government elections, with low levels of participation in public consultations and so-called participatory budgets. Quite often, authors point to Western European or Scandinavian countries as model examples of participation in local policy-making. New ways of encouraging people to participate more actively in the life of their municipality are indicated. In Poland, local democracy is still at the stage of building relationships between people and local governments based on trust, which relies on credibility and transparency in public life. The creation of a sphere of trust is a long-term process directly connected with the change in the way of thinking about the role and place of citizens in local politics, and the role of its executive decision-making bodies at every local government level. The examples of Polish cities as Poznań, Warsaw, Gdańsk, Wrocław, Kraków and others, in which members of urban movements are becoming more and more active, show that the residents of these cities have untapped potential in terms of working for the benefit of their local community. The voice of residents on matters directly affecting them can help local authorities to make better decisions, addressing residents' needs in a more effective way.

The change in the perception of authority also applies to those who are in power. To a large extent, it is up to the latter whether they will involve wider groups of residents in local decisions, and which legal measures they will use to do so. They also have at their disposal informal channels of communication with residents, such as open meetings, during which topics important from the point of view of the district or city are discussed. With regard to mass public transportation management, the opening up of transporta- 
tion providers to the opinions of passengers is a step towards the better identification of transportation needs and passenger demands, regarding quality of service, the planning of new connections, architectural barriers limiting the availability of stops, or defining the frequency of a given service.

This study addresses the issue of the participation of residents in the activities of the city related to the organization of public transportation. In Germany, in addition to regular public consultations (on e.g. changes in timetables, plans to renovate transportation infrastructure, etc.), transportation providers work alongside public transportation passenger councils (appointed by the providers). Consequently, in the first part of the paper, the author will elaborate on the theoretical justification for the establishment of advisory bodies in public transportation, in the second part German and Polish models of passenger councils and their rights and responsibilities will be discussed, and in the third part the concept of a passenger council for the city of Poznań, which provides mass transit for the metropolitan area, will be presented. The aim of the study is to answer the following research problem: how can one involve residents of cities which organize public transportation (municipalities covered by the agreement/creating a local authority association) in the process of consultations and seeking opinions on urban transportation policy? The author puts forward a proposition that the deliberative nature of urban space management opens it up to residents, empowers and engages them, and builds new forms of identification with the locality. It changes the nature of the relationship between residents and the local government/local administration. The creation of high-quality, effective public policy requires an appropriate approach which facilitates mature deliberation in various forms. The author's reasoning is evaluated by answers to the following research questions: What are the conditions for and threats to deliberative local democracy? Which of the known deliberative theories describes local forms of consultation and opinion seeking with regard to public transportation passenger councils? What are the means used by the residents of Western European cities to influence transportation policy? Are there any examples of passenger councils in Poland? Which of the models which have been tried and tested in other cities can be implemented by the Poznan transportation provider?

\section{A review of literature on contemporary cities}

It is easier to observe macro processes of social change taking place in cities than in other places. According to Sassen, it is in big cities that globalization and the information revolution are taking place, where global capital is concentrated, and where vast numbers of immigrants settle (Piłat-Borcuch, 2012, p. 133; after Gałkowski, 2008, p. 95). In the context of urban planning, perceived as "the art of shaping space, and also as a field of science" (Paszkowski, 2011, p. 10), the city is considered to be a set of architectural and landscape forms, of symbols, values, and social structures, overlapping in time. They are an expression of human moral standing, and show current achievements in the area of technology, aesthetics or design. Consequently, urban space is an architectural challenge. It can be furnished in a specific way, determining the functions of specific quarters of the city, and thus influencing the city lifestyle. Hence, "in the shadow of great urban planning, alternative methods of social co-residence are being developed, which are a response to mega- 
development. These are the ideas of 'new urbanism,' 'smart growth' and the 'slow city,' which promote models of sustainable cities. They are based on social and spatial values, ignoring the developer-focused, profit-oriented, accelerated urban development model of new city districts and entire cities" (ibid., p. 13). At the same time, they propose a different model of resident participation in the life of a housing estate, district, or municipality. They encourage and somehow 'force' participation within various forums, at different levels of local decision making. Thus, a city is something more than just an agglomeration of units equipped with municipal goods, or a simple constellation of institutions and administrative systems. The city is a product of human nature (Jałowiecki, Szczepański, 2009, p. 19; after Park, p. 20), and is also shaped by human nature.

The city is a socio-political organism equipped with an administrative system to facilitate the management of public affairs. Researchers of contemporary cities emphasize the multifaceted nature of phenomena taking place in urban areas, which means that an interdisciplinary approach is required to capture, understand, and research this issue. The city is "a reflection of market forces in time and space, in which periods of both economic growth and economic and political crises are recorded. The city as a socio-cultural space is a place of exchange of thoughts, and a place of civilizational development reflecting the yearnings, aspirations, and culture of its residents" (Paszkowski, 2011, p. 17). Barber grasps this nicely by writing: "Regardless of whether or not urbanity lies in the nature of people, it is part of our history and - by coincidence or by choice - it defines the way we live, work, play, and create communities. Regardless of the contracts we design on a macro-scale, politics starts right next to us - in our neighborhood, and city" (Barber, chapter I).

Turning to residents is usually a conscious decision by city authorities, which involves residents in projects of key importance to them, such as economic activity, spatial development, transportation policy, housing policy, the provision of recreational space, and the establishment of local forms of nature protection. These are the subject of public debates and partnerships in the co-management of the city (Szymańska, Korolko, 2015, pp. 31 and 32). Among the available deliberative methods, one can distinguish the method of deliberative determination of public opinion preferences, the method of citizens' panels, the method of planning cells, and consensus conferences (Sroka, 2009, p. $120 \mathrm{ff}$.). These methods are an element of multi-stream management focused on the coordination of relationships between power centers and entities cooperating with these centers, especially in the situation of so-called incomplete contacts (ibid., p. 86), which characterize the societies of large urban centers (Tomaszyk, 2016, p. 208).

Civil participation in urban space has developed particularly well in large cities which have been assigned metropolitan functions. Such activities address the expectations of the changing community of residents, which, due to many factors, is becoming less stable and more heterogeneous (the so-called community of incomplete contacts). Cities forming agglomerations are characterized by a diversity of interests and the inflation of expectations and demands, which cannot always be met. Therefore, the inclusion of residents in the decision-making process is sometimes a conscious move by the authorities, in order to show how decisions are being made, and to engender responsibility for the consequences of such decisions. The concept of civic inclusion in urban development, known as 'smart governance,' is in fact a deliberative policy that connects societies - the political system with networks of the political public sphere (ibid., p. 209). "One of crucial outcomes of 
this process is a dynamic 'focus shift' in the relationship between the three main resources required for social integration, and political-and-administrative control" (Sroka, p. 26). The enthusiasm associated with the implementation of new forms of resident participation, also in relation to sectoral municipal policies, may be weakened by the lack or low level of deliberative capacity, understood by John Dryzek as "the extent to which a political system possesses structures to host deliberation that is authentic, inclusive, and consequential" (Juchacz, 2015, p. 431; after Dryzek, 2000, p. 1384). Importantly, inclusiveness is understood as actual inclusion of all stakeholders, and a wide range of discourses being present in a given political environment, while consequentiality is related to having - direct or indirect - influence on decisions or social changes (Juchacz, 2015, p. 432). Deliberation as such is threatened by a number of deep-rooted problems in the deliberative system, e.g. entrenched partiality denying the right to participate in a debate to certain groups (Juchacz, 2015, p. 405). Resistance to deliberation is a step backwards in the expansion of the sphere of public debate, since deliberation should open up space for residents, empower and engage them, and build new forms of identification with the locality. It changes the nature of the relationship between residents and the local government/administration. The creation of high-quality public policy requires an approach that facilitates mature deliberation in a variety of forms. It should lead to the creation of rational knowledge, showing the scale and complexity of public problems (cf. Zybała, 2004, p. 4).

The incorporation of forms of deliberation within urban spaces and current local authority policies must not be limited solely and exclusively to the use of obligatory forms of social consultation. An interesting concept of an integrated deliberative system was formulated by Carolyne Hendriks.

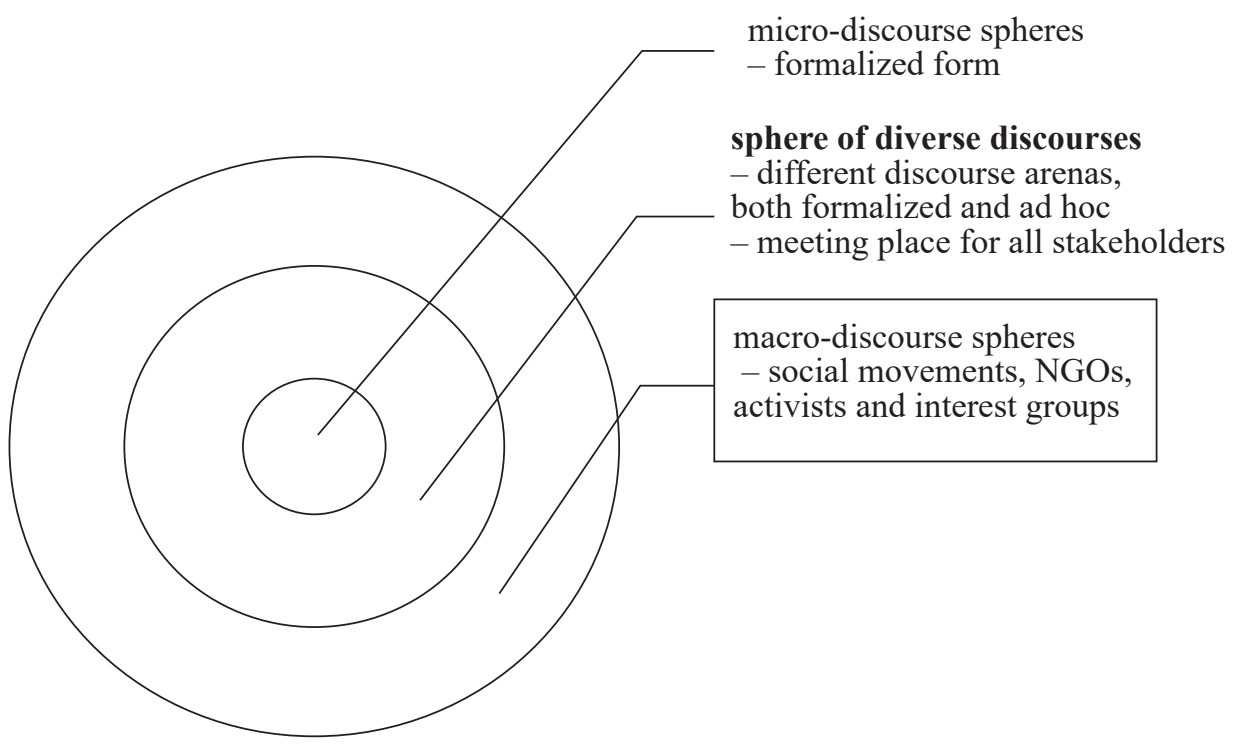

Figure 1. The spheres of deliberative discourse according to Carolyne Hendriks

Source: Own compilation on the basis of: W. P. Juchacz (2015), Deliberatywna filozofia publiczna. Analiza instytucji wystuchania publicznego w Sejmie Rzeczpospolitej Polskiej z perspektyw systemowego podejścia do demokracji deliberatywnej, Poznań. 
According to the diagram above, the system of deliberative discourse consists of "a number of different discursive spheres, i.e. areas in public space within which deliberation takes place" (Juchacz, 2015, p. 420). The key task of a well-functioning deliberative system in a city is the creation of links between the various arenas of deliberation, and the elimination of exclusion from the debate (cf. Juchacz, 2015, p. 420). In reference to the public transportation passenger councils discussed in this study, out of the three spheres discussed by Hendriks, the macro-discursive sphere encompasses in its description the form of passenger activity. It is characterized by a low level of formalization, a broad forum for debate allowing for the representation and activity of social movements, non-governmental organizations (NGOs), activists, interest groups, or opinionformers (cf. Juchacz, 2015, p. 423). The creative exchange of ideas between different types of players combines broader public discourse with the discourses and decisions of the political elite (cf. Juchacz, 2015, p. 423; after Hendriks, p. 501).

\section{German models of passenger councils}

The existence of passenger councils established alongside and by providers of passenger transportation are a characteristic feature of the German model of the organization and management of public passenger transportation. The work of passenger councils is an expression of the openness and trust of the provider towards passengers and local residents.

Of the numerous responsibilities of the providers of passenger transportation in urban public transportation, some can be carried out in cooperation with the users of the services. These include, but are not limited to:

a) Studying and analyzing needs in public transportation, taking into account the needs of the disabled and those with reduced mobility;

b) Taking action to implement or update an existing transportation plan;

c) Ensuring appropriate conditions for the operation of public transportation, in particular by defining standards for stops and stations, rules of using stops and stations, the operation of integrated transportation hubs, integrated tariff-and-ticketing systems, and passenger information systems;

d) Determination of transportation stops and stations owned by local government units and those belonging to other owners;

e) Setting fares and other charges for services provided by the operator within the scope of public transportation (Act on Collective Public Transportation, Article 15).

The figure below illustrates the German model of passenger councils and the providers of public transportation.

As can be seen from the diagram above, German passenger councils are formed at the initiative of transportation providers, service providers, or transportation branches of municipal associations. Their members, some of whom are directly elected, meet regularly on predetermined dates (cf. Meyer-Liesenfeld, 1999, p. 89; cf. Schnippe, 2000, p. 176). There are known examples of passenger councils consisting only of representatives of users of public transportation, but equally popular are 'mixed councils' representing the transportation provider, carriers, and other institutions whose competences 


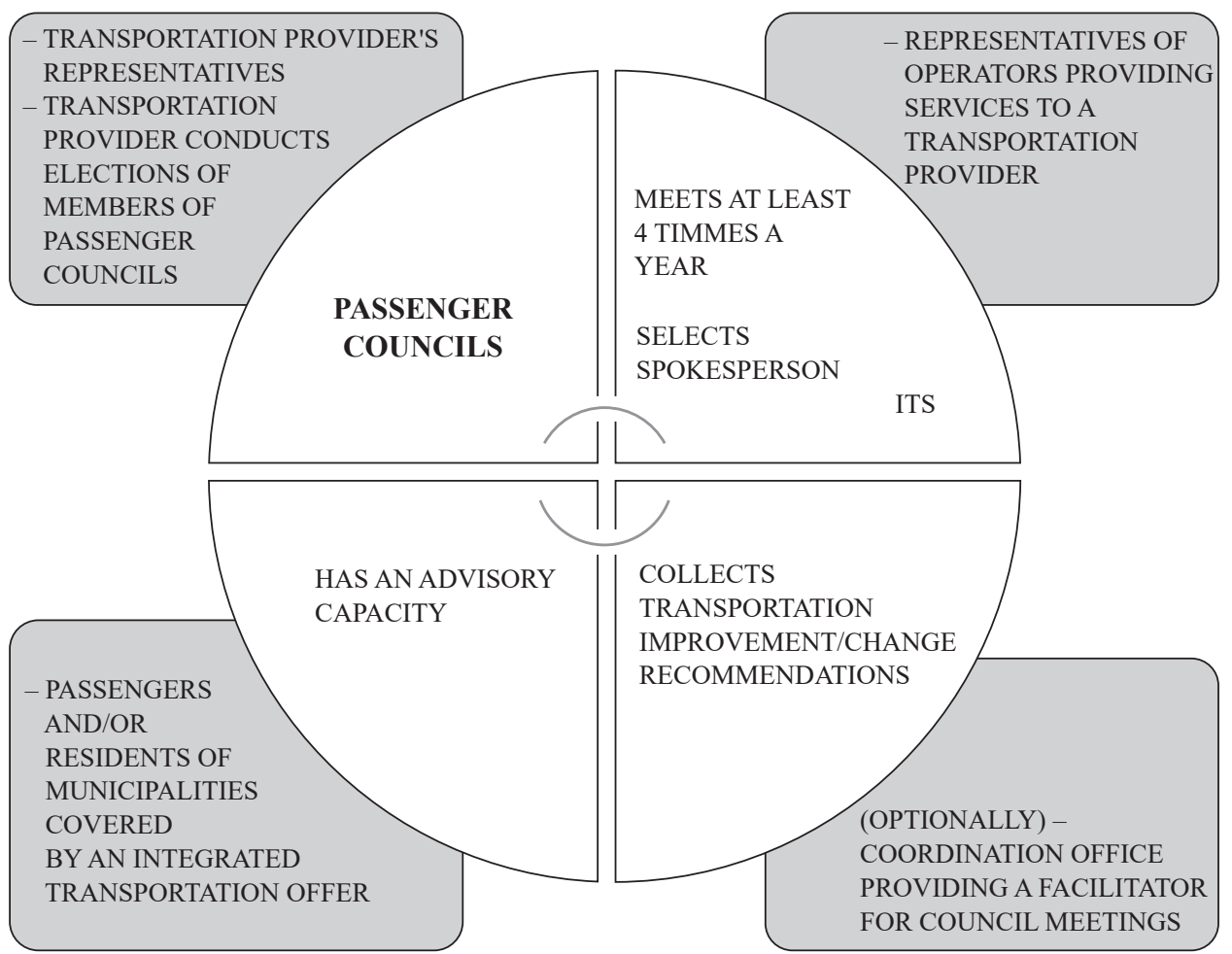

Figure 2. German model of public transportation passenger councils

Source: Own compilation.

lie in the field of urban transportation. For example, the Frankfurt-am-Main passenger council, which has been in operation since February 27, 1997, consists of the widest possible representation of local public transportation policy bodies, residents of municipalities covered by the transportation network, and passengers. Due to the ongoing evaluation of the council's work, this group underwent a reform in June 2013 (Fahrgastbeirat FF Main: Konzepzion). The council is composed of 11 representatives of passengers, and the following entities:

- cyclists - Allgemeiner Deutscher Fahrrad-Club;

- student self-government - Allgemeiner Studierenden-Ausschuss (AStA) der Universität Frankfurt a. M.;

- economic self-government - Deutscher Gewerkschaftsbund, Region Frankfurt/ Rhein-Main;

- disabled people - Frankfurter Behinderten-Arbeitsgemeinschaft (FBAG);

- industry and trade representatives - Industrie- und Handelskammer Frankfurt am Main;

- immigrant representatives - Kommunale Ausländer- und Ausländerinnenvertretung;

- pro-railway association representatives - Pro Bahn, Regionalverband Großraum Frankfurt; 
- senior citizens - Seniorenbeirat der Stadt Frankfurt am Main;

- parents' council representatives - Stadtelternbeirat Frankfurt am Main;

- transportation enthusiasts' club - Verkehrsclub Deutschland (VCD). ${ }^{1}$

Passengers who are not members of the council may submit their motions, complaints, and recommendations in writing, by e-mail or by phone. Applications submitted in this form are handled by the customer service center, traffiQ. ${ }^{2}$

The average number of council members in Germany ${ }^{3}$ is between 12 and 50 people. Passenger representatives are most often chosen in direct elections from among the candidates submitted by authorized associations, urban movements, and groups of passengers. Contrary to the well-known clubs of public transportation customers in Germany, passenger councils should represent the widest possible representation of residents who do not use trams or buses on a daily basis. Their observations and remarks are important for the development of solutions that will win over new, preferably regular customers, and thus contribute to the change of the local mobility culture.

In Bremen, for example, the council has been appointed as coordinator of the dialog between service providers and customers, and the passenger transportation provider. The council meets six times a year. As a rule, members are responsible for cooperating to plan the network of connections throughout the association, evaluating the current and planned transportation system, and bringing quality-improving requests both to carriers and to the association's board. The council is divided into working groups, which meet once a month. The term of office of the council members is three years. The council consists of 19 members, of which six are members designated by the transportation association, and 13 are representatives of the residents.

The councils have a consultative and advisory nature, and allow the transportation provider to take up topics often overlooked by the administration, and propose changes. In order to give credibility to the establishment of such advisory bodies, the role of the transportation provider and carriers must be reduced to analysis of the proposals in terms of their implementation, and to the systematic implementation of the proposals voiced by the council. The method of operation of the council makes sense only if the outcomes of its work are practicable. The discussion of urban transportation and mobility will be authentic only if it takes place without any means of coercion. The decision-making system in this area must be deliberative, i.e. it must have structures that enable deliberation to take place.

Unlike the German councils, the powers of their British counterparts are broader. British members of passenger councils can co-decide on fares and ticketing systems, as well as changes to the connection network. They also spend some of their budget on the promotion of public transportation and the co-financing of the upgrading of stops, or the elimination of minor architectural barriers. In the case of Austrian advisory bodies, the scope of advisory and decision-making competencies includes, inter alia, timetables,

${ }^{1}$ https://www.traffiq.de/1487.de.fahrgastbeirat.html\#a71714.

2 E-Mail: fahrgastbeirat@traffiQ.de.

${ }^{3}$ Passenger councils are active in the following German lands: Baden-Württemberg, Bavaria, Berlin, Brandenburg, Bremen, Hamburg, Hesse, Mecklenburg-Western Pomerania, Lower Saxony, North Rhine-Westphalia, Rhineland-Palatinate, Saarland, Saxony, Saxony-Anhalt, Schleswig-Holstein, Thuringia. 
fares, public transportation lines, adjustment of the fleet or rolling stock to align with passenger volumes, quality of service, and tidiness of stops and public transportation vehicles (Blümel, 2004, p. 72).

\section{Polish examples of passenger councils - the Warsaw Public Transportation Council}

Among the Polish cities whose authorities provide public transportation, only the Capital City of Warsaw has decided to establish a passenger council. The composition, competence, method of selecting members, and authorization and time schedule of meetings of the Warsaw Public Transportation Council are similar to their German equivalents. According to the adopted Regulations (Regulamin), the electoral body of the council members is the Public Transportation Authority in Warsaw. Entities specified in the Regulations have the right to propose candidates for members of the council. The regulatory framework of the council assumes that it is an opinion-forming and advisory body under the Director of the Public Transportation Authority. The Warsaw Public Transportation Council is composed of representatives of the following entities: NGOs operating in the Capital City of Warsaw, representatives of operators, and representatives of self-government units of the Warsaw urban agglomeration and those municipalities which have signed an inter-municipal agreement with the Capital City of Warsaw on joint organization and management of public transportation. The council consists of a total of 18 members. The number of elected seats is limited to 10. As in other councils, the elected seats are defined by type as follows: 2 - for representatives of environmental NGOs; 2 - for NGOs operating in the field of social interest and social assistance, but not represented in the Sectoral Committee for Social Dialog of the Capital City of Warsaw, of which 1 seat is for a representative of the disabled; 2 - for business NGOs; 1 - for a representative of the Transportation Sectoral Committee for Social Dialog; 2 - for representatives of local government units of the Warsaw urban agglomeration, save that 1 seat is for representatives of those units which have signed an inter-municipal agreement with the Capital City of Warsaw on the organization of bus and train transportation, while the second seat is for those units which have signed an agreement exclusively for transportation services provided by bus. One seat is for the operators of the services provided. To ensure the continuous work of the council, a solution was introduced whereby appropriate entities designate so-called reserve members. The other rules of electing council members seem self-explanatory, for example, members must not remain in an employment relationship with the Warsaw City Office, or limiting the number of candidates designated by authorized entities to one. In accordance with Section 2(8) of the Regulations, a person may become a council member if they have the support of at least two NGOs acting for the development of the Capital City of Warsaw, or 5 municipalities of the Warsaw urban agglomeration, or three operators (Regulamin).

During the council's current term of office, in March 2018 representatives of individual entities were elected during two meetings initiating the establishment of the Warsaw Public Transportation Council. If there is disagreement and no candidates 
with the required support are put forward, the exclusive right to appoint members of the council is vested in the Director of the Public Transportation Authority. The correct procedure for electing members of the Passenger Council at the Warsaw Public Transportation Authority is overseen by the Electoral Commission (appointed by the WPTA), which also verifies documents confirming the status of the association and candidates' letters of support, and prepares a shortlist of members positively verified for approval by the Director of the Public Transportation Authority. The council also includes experts representing the academic community. Formally, members of the Warsaw Public Transportation Council are appointed by the Mayor of Warsaw. Members hold their term of office for three years. A person ceases to be a member of the council upon taking up employment in the Warsaw City Office, or after a decision by the Director of the Warsaw Public Transportation Authority on a motion signed by at least two-thirds of the Warsaw Public Transportation Council. The Regulations also specify the maximum number of members of the Council, which is 20 . However, in justified cases, the Public Transportation Authority Director may expand this group.

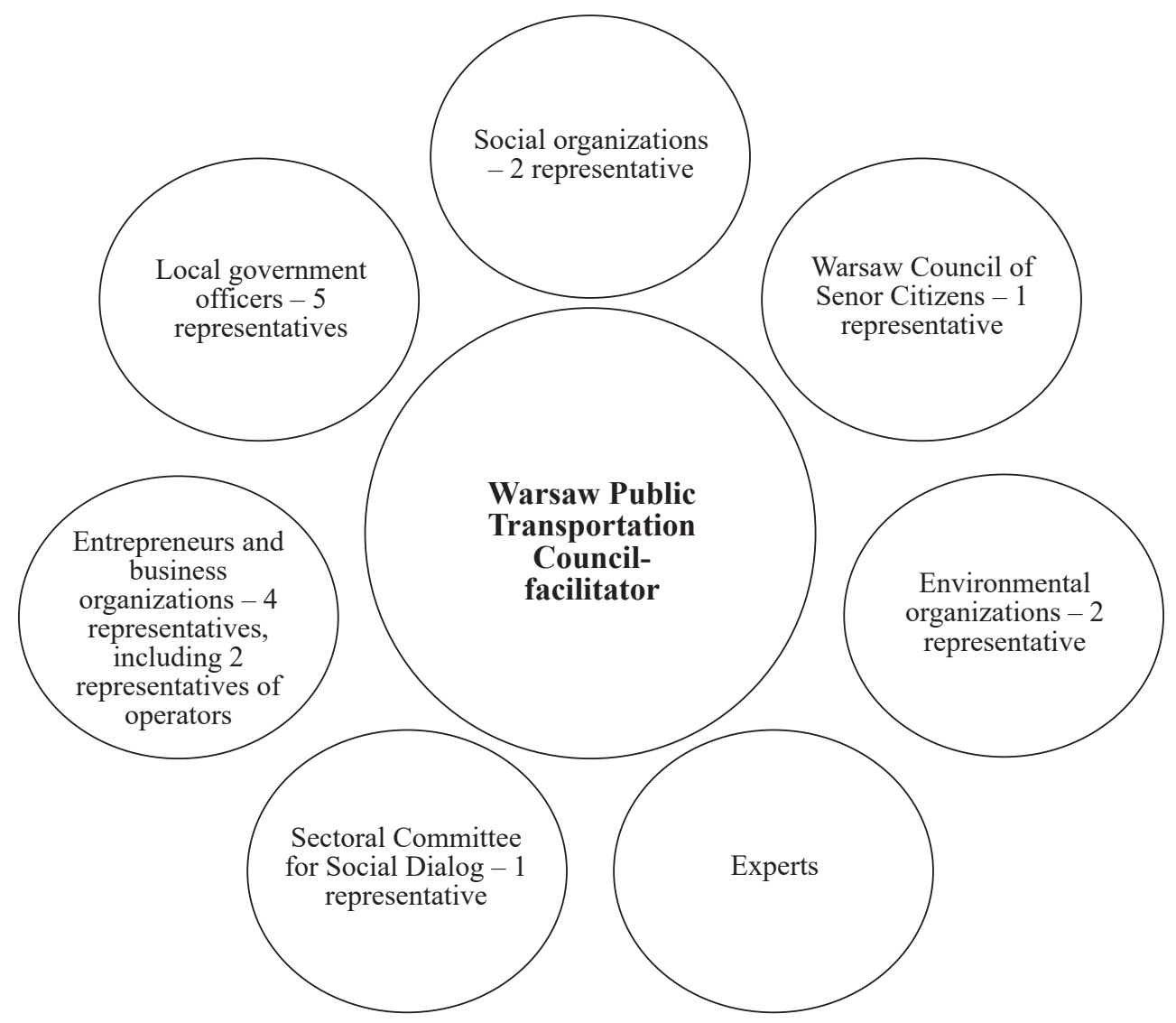

Figure 3. Composition of the Warsaw Public Transportation Council

Source: Own compilation 
A facilitator leads the work of the council. The council takes decisions by consensus. Should there be no agreement, an additional working group is set up to reach a consensus. The proceedings of the working group can be supported by an independent expert. Twice a year, the Public Transportation Authority organizes open meetings with residents, attended by council members, during which council members have the opportunity to report on their activities and opinions. This is also a well-established practice in Germany, where a so-called transportation forum or a mobility forum is organized. The council meeting agenda is drafted on the basis of submissions made during consultation and election meetings with NGOs and local government units of the Warsaw urban agglomeration. Additional topics can be submitted for discussion as so-called extraordinary motions, subject to approval by at least half of the participants of the council meeting (cf. Rada Warszawskiego Transportu Publicznego). The council's meeting schedule shows that it meets once a month in the offices of the Director of the Public Transportation Authority. The diagram shows the order of the Warsaw Public Transportation Council decision making process.

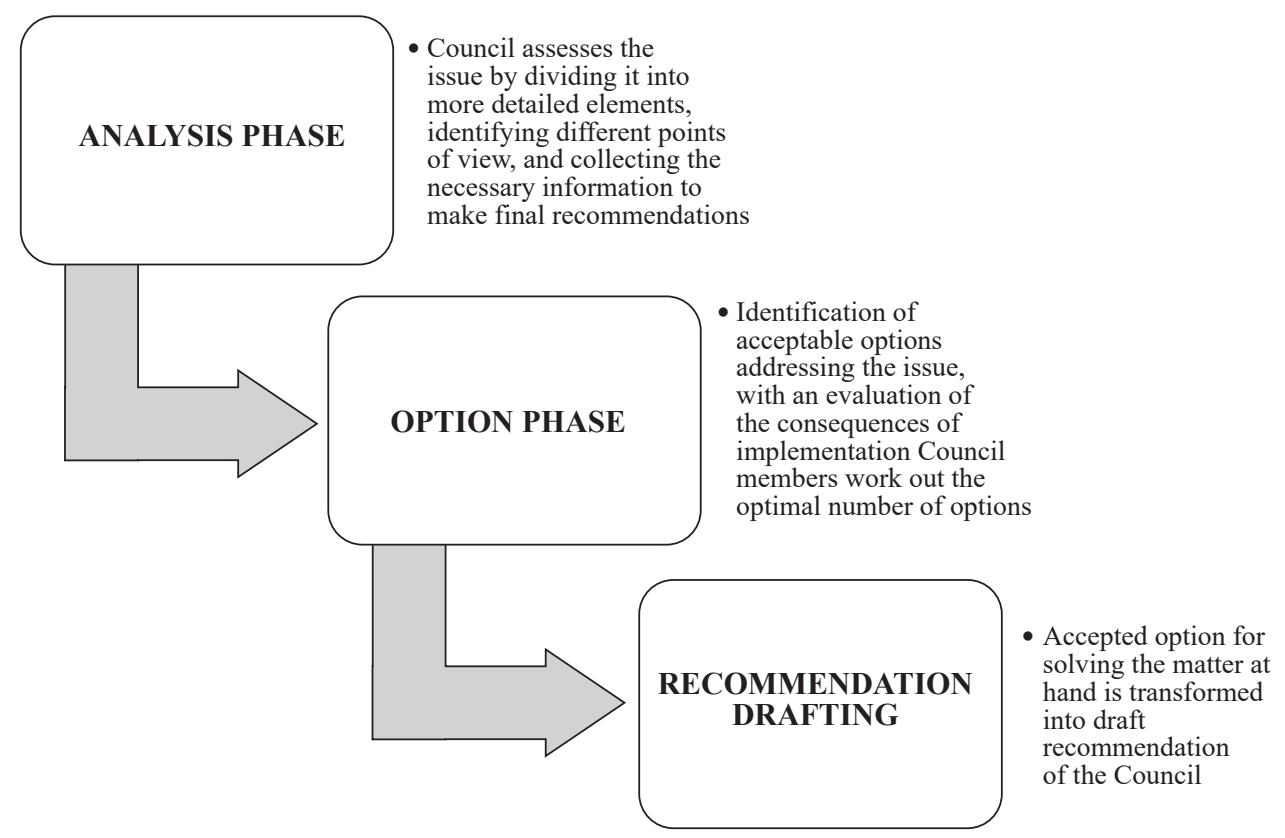

Diagram 1. Phases of the decision-making process of the Warsaw Public Transportation Council

Source: Own compilation based on the Rada Warszawskiego Transportu Publicznego - zasady funkcjonowania, Warszawski Transport Publiczny, ppt., downloaded from: http://www.ztm.waw.pl/?c=711\&l=1 on August 12, 2018.

The Warsaw passenger council is the only Polish example of formal cooperation between passengers, representatives of NGOs, public transportation operators, transportation providers, and experts. Hopefully, the results of the work of this body will inspire other transportation providers. 


\section{The concept of the Poznań Urban Transportation Authority's Poznań passenger council}

The work on the Poznan passenger council is at the stage of exchanging views and drawing up preliminary concepts. In Poznan, more and more importance is attached to a participatory style of city management, and social activists and other residents are invited to discuss the city and its future. An unambiguous evaluation of these measures from the point of view of deliberative democracy would require more in-depth research and a separate study. Given that the integrated public transportation system covers almost all municipalities within the Poznań urban agglomeration of around 900,000 people, and in light of the city's efforts to improve environmentally friendly mobility, combined with its current low numbers of public transportation users, the establishment of a public transportation passenger council in the city is worthy of consideration. The competences of the Poznan passenger council could draw on the above-mentioned examples. Members of the Poznań passenger council could give oral and written representation. A written representation would be required, for example, to change transportation regulations, fares and fare reductions, changes in the public transportation sustainable development plan, changes in the bus and tram line layout, and changes in the bus and tram timetables concerning the frequency of services. Additionally, the passenger council, in its advisory capacity, would serve the transportation provider under the Poznań Urban Transportation Authority in the following areas:

1) Quality of transportation services provided by system operators selected by the provider and related to: punctuality, cleanliness of vehicles and stops, driving culture, the visual appeal of vehicles and stops, legibility of timetables, efficiency of passenger information, environmentally-friendly transportation, trip comfort, etc.;

2) Day and night connection frequencies;

3) Location of Poznań City Bike stations;

4) Identification and elimination of architectural barriers in accessing stop infrastructure;

5) Offers of private providers of car and bike sharing services;

6) Passenger friendliness tests for new means of transportation;

7) Availability of brick-and-mortar and electronic ticket purchasing points;

8) Fare policy in the city of Poznań;

9) Urban public transportation development direction.

Whenever a written opinion is mandatory, the issuance of such an opinion would require the consensus of the council members present at a meeting of the passenger council. Should a consensus be not possible, the facilitator of the council operations could appoint a working group composed of council members and chaired by an external expert. The council could meet once quarterly at the offices of the Urban Transportation Authority. The council would work under the direction of a facilitator chosen by the Director of the Urban Transportation Authority from outside its members. Council meetings would be convened at least quarterly, or more frequently at the request of the Director of the Urban Transportation Authority. The council would submit a report on its operations to the Director of the Urban Transportation Authority by the end of the first quarter. The term of office of the council, due to the five-year term of office of the local 
government, would be 2.5 years. The mandate of a passenger council member could be renewable. No remuneration should be paid to members of the passenger council for their work. However, in order to encourage active participation, it should be possible to give directly-elected members 3-month tickets for the entire public transportation network. It would not be possible for elected council members to be employees or family members of employees of operators with whom the Poznań Urban Transportation Authority has a signed contract for the provision of transportation services, or employees of the local government administration of the Poznań agglomeration municipalities.

All registered residents of municipalities for which the City of Poznan is the provider of passenger transportation would have the right to vote for the council members. The right to stand as candidates for the council members, on the other hand, would be given to all registered residents of municipalities covered by the Urban Transportation Authority system, who on the day of submitting their candidacy are at least 15 years of age, hold a PEKA (Poznań Electronic Agglomeration Card) card and have purchased a periodic ticket for a tram or bus line or for the whole network in the current calendar year, or who, in the current or previous calendar year, made at least two t-wallet transactions.

The right to propose directly-elected candidates for the passenger council would be granted to persons or entities registered in one of the municipalities covered by the joint Poznań system of public transportation, representing:

a) registered disabled people with reduced mobility;

b) visually impaired or blind people;

c) alliances of Poznań university student self-governments;

d) further education colleges;

e) municipal youth councils;

f) auxiliary units - villages, housing estate councils;

g) NGOs acting for the benefit of the local community;

h) entrepreneurs and institutions representing them.

Each of the entities meeting the above criteria would have the right to nominate one candidate. A nominated candidate would have to be supported by at least three sectoral organizations operating in the area covered by the network of the Poznan Urban Transportation Authority. Nine members of the council would be elected by all people who have the right to vote electronically via an account in the Poznań Electronic Agglomeration Card system. The Poznań passenger council would also include employees of the Urban Transportation Authority (appointed by the Director), and employees of the Poznań Municipal Roads Authority (appointed by the Director). Representatives of system operators with whom the Urban Transportation Authority has signed transportation service contracts, as well as representatives of municipalities, should be represented on an equal rotational basis. Figure 4 shows the proposed membership of the Public Transportation Passenger Council.

After the selection of the entire passenger council, its first meeting should be convened by the Director of the Urban Transportation Authority. At the first meeting, the members would elect three members who would form the executive committee of the council. The executive committee would consist of a facilitator and two members selected from the elected council members. Overall, the passenger council would consist of 17 members. The work of the passenger council could be supported by subject-matter 
experts with appropriate knowledge and experience. However, their number would be limited to two, they would have only an advisory capacity, and they would have none of the rights enjoyed by council members.

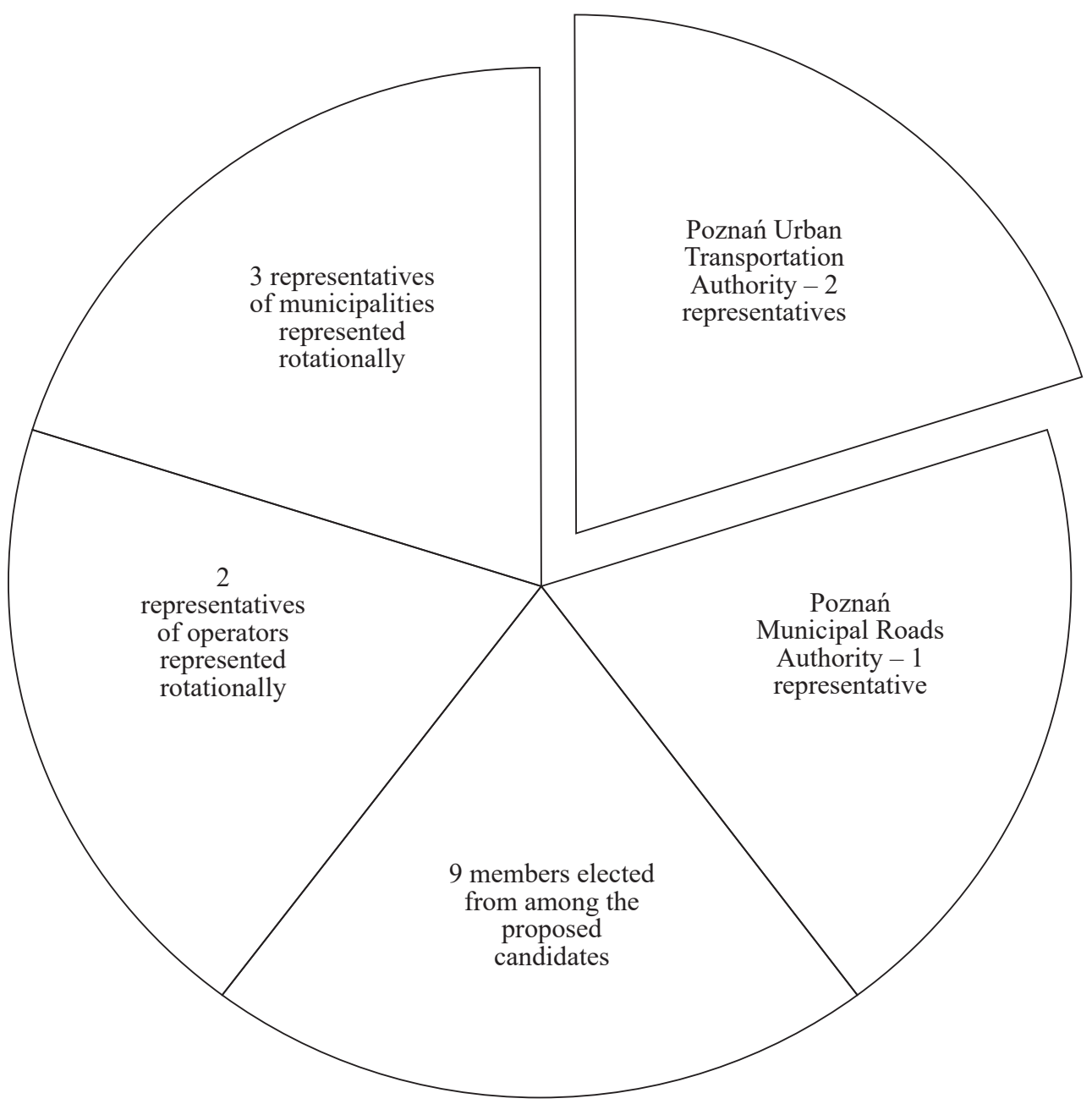

Figure 4. Membership proposal of the Poznań Public Transportation Passenger Council

Source: Own compilation

\section{Summary}

The aim of the study was to answer the research problem formulated in the introduction. In the performance of its statutory tasks, the public transportation provider may involve residents and passengers. Due to the fact that public transportation policy is strongly correlated with residents' needs, in order to implement it effectively, passenger demands and needs should be very well understood, and an ongoing evaluation 
of them should be carried out. To that end, states with longer democratic traditions use deliberative methods of involving residents to jointly decide on local policies. German, British, and Austrian transportation providers or operators set up passenger councils in order to tailor providers' services to the needs of the local population. The councils are advisory bodies, but in the UK they have a budget, and co-decide on the allocation of the budget. The deliberative nature of urban space management opens it up to residents, empowers them, and engages and builds new forms of identification with the locality. It changes the nature of the relationship between the residents and local government/local administration. The creation of high-quality, effective public policy requires an appropriate approach that facilitates mature deliberation in various forms. Polish local governments are becoming more open to new trends in thinking about the city, its function, and its role in the lives of residents, but also in relation to their functional areas. Residents have the right to expect a change in the carrying out of public duties. With regard to public transportation, only the authorities in Warsaw have decided to take advantage of Western European experience and set up the first public transportation council in Poland. This way of implementing current transportation policy can be mutually beneficial.

\section{Bibliography}

Barber B. R. (2014), Gdyby burmistrzowie rzadzili światem. Dysfunkcyjne kraje, rozkwitajace miasta, Warszawskie Wydawnictwo Literackie MUZA SA, Warszawa, chapter 1, Transl.: H. Jankowska, K. Makaruk.

Blümel H. (2004), Mobilitätsdienstleister ohne Kunden: Kundenorientierung im öffentlichen Nahverkehr (Discussion Papers/Wissenschaftszentrum Berlin für Sozialforschung, Forschungsschwerpunkt Organisationen und Wissen, Abteilung Innovation und Organisation, 2004-109), Wissenschaftszentrum Berlin für Sozialforschung gGmbH, Berlin, http://nbn-resolving.de/ urn:nbn:de:0168-ssoar-117891.

Dryzek J. S. (2000), Deliberative Democracy and Beyond, Liberals, Critics, Contestations, Oxford University Press, Oxford.

Fahrgastbeirat Frankfurt am Main: Konzeption 2014 (PDF, 0.1 MB).

Gałkowski J. P. (2008), Socjologia miasta w epoce globalnej, in: "Kultura i polityka" (Miasto) 4/2008, ed. J. Lubecka, Wyższa Szkoła Europejska im. Ks. Józefa Tischnera, Kraków.

Hendriks C. M. (2006), Integrated deliberation: Reconciling civil society's dual role in deliberative democracy, "Political Studies," vol. 54, https://www.traffiq.de/1487.de.fahrgastbeirat. html\#a71714.

Juchacz W. P. (2015), Deliberatywna filozofia publiczna. Analiza instytucji wystuchania publicznego w Sejmie Rzeczpospolitej Polskiej z perspektyw systemowego podejścia do demokracji deliberatywnej, Poznań.

Park R. E. (2009), The City: Suggestion for Investigation of Human Behavior in an Urban Environment, "The American Journal of Sociology" 1915, vol. 20, after: B. Jałowiecki, M. S. Szczepański, Miasto i przestrzeń w perspektywie socjologicznej, Wydawnictwo Naukowe Scholar, Warszawa.

Paszkowski Zb. (2011), Miasto idealne w perspektywie europejskiej i jego zwiazki z urbanistyka wspótczesna, Universitas, Kraków.

Piłat-Borcuch M. (2012), Socjologia miasta jako źródło wiedzy na temat zarządzania miastem, „Studia i Materiały, Miscellanea Oeconomicae," Rok 16, nr 2. 
Rada Warszawskiego Transportu Publicznego - zasady funkcjonowania, Warszawski Transport Publiczny, ppt., http://www.ztm.waw.pl/?c=711\&l=1, 12.08.2018.

Regulamin wyboru przedstawicieli organizacji pozarzadowych i jednostek samorzadowych $i$ operatorów na członków Rady Warszawskiego Transportu Publicznego, http://www.ztm.waw. $\mathrm{pl} / ? \mathrm{c}=711 \& \mathrm{l}=1,12.08 .2018$.

Schnippe Ch. (2000), Psychologische Aspekte der Kundenorientierung: die Kundenzufriedenheit mit der Qualität von Dienstleistungsinteraktionen am Beispiel des ÖPNV, Lang.

Sroka J. (2009), Deliberacja i rzadzenie wielopasmowe. Teoria i praktyka, Wrocław.

Szymańska D., Korolko M. (2015), Inteligentne miasta. Idea, koncepcje i wdrożenia, Wydawnictwo Naukowe Uniwersytetu im. M. Kopernika, Toruń.

Tomaszyk M. (2016), Przykłady działań polskich i niemieckich organizatorów publicznego transportu zbiorowego na rzecz partycypacji mieszkańców miast w bieżacym koordynowaniu i zarzadzaniu siecia transportu miejskiego, "Przegląd Politologiczny," nr 4, Wydawnictwo Naukowe WNPiD UAM, Poznań.

Turzyński M. (2015), Analiza delimitacji gdańskiego obszaru metropolitalnego i jego stref, "Rozwój Regionalny i Polityka Regionalna," 29.

Uziębło P. (2009), Demokracja partycypacyjna, Gdańsk.

Zybała A. (2013), Polityki publiczne wobec wzorców zarządzania publicznego, "Zarządzanie Publiczne," nr 4(26), Kraków.

\section{Udział mieszkańców miasta w bieżącej działalności podmiotów świadczących usługi transportu publicznego}

\section{Streszczenie}

Organizacja i zarządzanie transportem publicznym jest jednym z najważniejszych zadań władz lokalnych. Ze względu na dynamicznie zmieniające się warunki polityki transportowej nowoczesnych miast, działania w tym zakresie stanowią wyzwanie, polegające na standaryzacji transportu i jego dostosowaniu do potrzeb i oczekiwań transportowych mieszkańców nie tylko poszczególnych miast, ale całych obszarów metropolitalnych. Jednym ze sposobów dostosowania transportu do potrzeb mieszkańców jest ciągła koordynacja na podstawie diagnozy i analizy wymagań mieszkańców. Rady pasażerów transportu publicznego stanowią forum wymiany poglądów na ten temat. W Polsce tylko władze Warszawy zdecydowały się dotychczas na powołanie takiego organu.

Słowa kluczowe: miejskie zarządzanie transportem publicznym, obszary funkcjonalne dużych miast, uczestnictwo obywatelskie 
